\title{
Analysing Liquidity, Credit Risk and Deposit Money Banks Profitability in Nigeria
}

\author{
Hieu Minh, VU \\ Faculty of Business Administration \\ Van Lang University, Vietnam \\ vuminhhieu@vanlanguni.edu.vn
}

Article History: Received: 10 November 2020; Revised: 12 January 2021; Accepted: 27 January 2021;

Published online: 05 April 2021 Abstract: This study examined the impact of liquidity and credit risk on profitability of selected deposit money
banks(DMBs) in Nigeria. The study adopts an empirical longitudinal research design and used data set covering 7-year
period from 2012 to 2018 from the annual reports of five DMBs. Pearson Correlation and multiple regression techniques
were used in empirical analysis and testing of hypotheses. The result shows that there is a significant relationship between
liquidity and profitability measured as return on equity (ROE). There is an insignificant relationship between credit risk
variables and profitability (ROE). The paper recommends that optimal level of liquidity should be maintained to reduce cash
sterility in the assets of banks. Though credit risk is not a main determinant of bank profitability; effective strategies should
be put in place to monitor, control and manage credit risk.

Keywords:Banks, Credit risk, Liquidity, Non performing loans, Return on equity

\section{Introduction}

Through the financial services they provide, banks are essential to economic growth. It can be argued that their position in intermediation is a stimulus for economic development. Banking crises have developed many times throughout history when one or more risks materialise. Because of its significant implications, the loss of banks has become a problem for the Central Bank of Nigeria and the owners of those banks. Banks are exposed to high risk as a result of lending and their inability to attract deposits. Greening and Bratanovic (2009) considered that credit risk (non-performing loans) is an incentive for the debtor of a financial instrument (individual, business or country) not to repay cash flows connected to capital and investment under the conditions stated in the credit agreement. Various factors may affect a borrower's ability to repay loans as they fall due. Delay in making repayment may cause cash flow and liquidity problem for the banks. Banks face the possibility that if they come due, creditors will not be sufficient to repay principal and interest. Between 1994 and 2000 a total of 33 banks were liquidated in Nigeria due to high non-performing loans in excess N200 billion (Nwaze, 2006). Studies has been done on credit risk and profitability of banks in Nigeria and Africa (Ejoh, Okpa and Inyang, 2014; Lartey et al., 2013; Kargi,2011; Owojori, Akintoyeand Adidu, 2011; Boahene, Dasah and Agyei, 2012; Kolapo, Ayeniand Oke, 2012) in the other part of the world,(Wild, Subramanyam and Halsey, 2007; Felix and Claudine,2008; Javaid, 2011; Al-Khouri,2011; EpureandLafuente, 2012; Chen and Pan 2012).

Liquidity managementhas received attention from researchers in Nigeria and Africa (e.g. Ejoh, Okpa and Inyang, 2014; ObiakorandOkwu, 2011; Uremadu, 2012; Ibe, 2013; Agbadaand Osuji,2013; Maaka, 2013) other parts of the world (e.g. Goddard et al.,2004; Heibati et al., 2009; Bordeleau et al.,2010; Imad et al.,2011). Existing experience of credit risk, liquidity control and profitability has been applied to the outcomes of these studies. All the research examined the relationship between credit risk, liquidity management and profitability. However, few researchers have analysed the mutual effect on the profitability of deposit money banks in Nigeria of credit risk and liquidity.In Nigeria, studies on the subject that uses data beyond 2014 is scanty. This gap is addressed by investigating the effect of both credit risk and liquidityon the profitability (ROE)of DMBs by using data from 2012 to 2018 annual reports of sample DMBs. It is quite essential for the organization to define risk acceptance requirements, express and handle risk-related lending practices and liquidity, considering the market lack of faith arising from bank distress that has afflicted the financial sector in the last decade.

The paper seeks to answer the follow questions.

iWhat is the relationship between credit risks and profitability?

ii What is the impact of liquidity on profitability?

\section{Literature Review}

\subsection{Bank Profitability and Non-Performing Loans}


Banking sector's profitability is of major concern for those who are responsible for policy making. Banks profitability could be measured by the return on equity which shows the extent shareholder equity is used to generate profits. The goal of risk management is to minimize foreign exchange losses, cashflows fluctuations and increase profitability and survival of banks. Return on equity (ROE) is a significant performance metric because it reflects how much profit a business will make on equity capital (Wild, Subramanyam and Halsey, 2007). ROE is described as the annual net profits after tax of the corporation divided by shareholder equity. A rising ROE will mean that without the infusion of new money into the business, the profit rises. In addition, ROE takes the retained earnings from the previous periods into account and tells the investors how efficiently the capital is reinvested. Banks exist to manage risk and provide a return to providers of capital.

Non-performing loan ratio is an important measure of credit risk. Greening and Bratanovic (2009) considered that credit risk (non-performing loans) is the probability that a financial transaction (individual, business or country) debtor would not repay cashflows corresponding to principal and investment under the terms stated in the credit agreement. Various factors may affect a borrower's ability to repay loans as they fall due. Delay in making repayment may cause cash flow and liquidity problem for the banks. Non- performing loans (NPL) represent loans and advances that are not serviced as at when due. If the creditor makes payment on both principal and interest when they come due, a loan has been shown to be performing.If non-performing loans could be defined as sub - standard, questionable or missing. Bank loans in the lost group prohibit banks from meeting their defined goals (Kolapo, AyeniandOke, 2012). The risk of incurring losses due to the inability of borrowers to pay back loans granted to them is mostly faced by banks. In Kenya, Muasya (2009) submits that non-performing loans influence the performance of commercial banks in the time of global financial crises.

The impact of credit risk management on the efficiency of deposit money banks in Nigeria was discussed by Harcourt (2017). Credit risk management factors have been found to dramatically impact the efficiency of deposit money banks calculated by equity returns (ROE). Boahene, Dasah and Agyei (2012) in a study of the relationship between credit risk and profitability of banks in Ghana using return on equity as a measure of profitability and ratio of nonperforming loans to total assets as a measure of credit risk. They find that there is a link between the management of credit risk and Ghanaian banks' profitability. The effect of credit risk on Nigerian banks' profitability has been analyzed by Kargi (2011). Financial statistics included as bank profitability and credit risk metrics were obtained from the 2004-2008 annual reports and accounts of six banks and analyzed using correlation and regression strategies. The study uses the ratio of non-performing loans to total loans and total loans to deposits as credit risk measures. Return on assets was used as profitability measure. He identified that credit risk (loans and advances) had a huge effect on Nigerian banks' profitability. It was assumed that the profitability of banks is inversely affected by the rates of loans and advances that represent a major risk of illiquidity and distress to these banks.Similarly, Kolapo, AyeniandOke (2012) evaluated the impact of credit risk on commercial Bank performance in Nigeria using a panel model approach. From the 2000-2010 annual reports and accounts of five banks, financial ratios included as indices of bank profitability and credit risk was analysed and interpreted using correlation and regression strategies. The study used ratios of nonperforming loans to total loans, total loans to deposits and loan loss provisions as credit risk measures. Return on assets was used as a performance measure. They find that credit risk (non-performing loans, loans and advances and loan loss provision) has a significant impact on the profitability of Nigerian banks. Badawi (2017) submits that higher NPL ratio worsens bank's credit quality and return on equity.

\subsection{Profitability and Loans and Advances}

The core of banking business is to create risk assets from deposit liabilities. Therefore, banks need articulated lending policy to effectively manage loans and advances.Owojori, Akintoye and Adidu (2011) posit that available statistics from the liquidated banks clearly showed that inability to collect loans and advances granted to customers and directors was a major contributor to the distress of the liquidated banks. The major risk faced by banks is the inability of borrowers to pay back. The success of their business depends on accurate measurement and efficient management of this risk, to a greater extent than any other risks. Banks are in the business of lending money and as such loans and advances constitute a significant portion of banks' statement of financial position. Kolapo, Ayeniand Oke (2012) evaluated the impact of credit risk on commercial Bank performance in Nigeria using a panel model approach using return on assets as a measure of profitability. Loans and innovations have been found to have significant effect on profitability. The effect of credit risk on the profitability of Nigerian banks was assessed by Kargi (2011). He claims that the control of credit risk (loans and advances) has a direct influence on the profitability of Nigerian banks. Accordingly, Kargi argued that the profitability of banks is inversely affected by the rate of loans and advances that place these banks at considerable risk of illiquidity and distress. 


\subsection{Profitability and Liquidity}

Banks are expected to honour their customers request in term of withdrawal and granting of loans. Illiquidity limits the ability of banks to meet these obligations. Liquidity from three distinct angles is considered by Bessis (2010). The first case is when, owing to factors pertaining to the scale of deposits, the amount of interest rates and their volatility and challenges in locating counterparty, the bank has trouble collecting funds at a suitable expense. The second angle sees liquidity as a safety cushion that, in tough conditions, helps win time. The final angle saw liquidity risk as a scenario in which major losses cause liquidity concerns and uncertainty about the bank's prospects. These will result in a large withdrawal of funds or the closure by other institutions of credit lines.Greening and Bratanovic (2009) say that liquidity changes to cover for anticipated and unpredictable changes in the balance sheet and to generate growth funds for banks. The rate of liquidity is a part of business dynamics and the perception by the market of the borrower's intrinsic risk.

Javaid (2011) conducted a study on the determinants of top 10 banks' profitability in Pakistan over the period of five years from 2004 to 2008 . The empirical results showed that total deposits have a strong influence on profitability. This, therefore, means that increase in total deposit would significantly lead to an increase in bank profitability. The interaction between liquidity and profitability of selected manufacturing firms in Nigeria was analyzed by Obiakor and Okwu (2011) and showed that while there was a trade-off between liquidity and profitability in the banks with a negative but negligible effect, the two factors were positively correlated. Badawi (2017) observed that liquidity does not affect bank profitability measured as return on equity (ROE). In the study of the efficacy of liquidity management and banking performance in Nigeria, Agbada and Osuji (2013) finds a significant relationship between efficient liquidity management and banking performance. They add that efficient liquidity management enhances the soundness of bank.Heibati et al. (2009) analysed and discussed the success of banks in the Persian Gulf region of Iran and the Arab countries. The study used cross-country panel data of the banks. The findings indicate that there is an interactive value between banks' liquidity and profitability, especially during the early phases of their operation.

\section{Methodology}

\subsection{Research Design}

This study adopts an empirical longitudinal research design and used data set covering 7 year period from 2012 to 2018 from five DMBs in Nigeria. Variables such as profit after tax, total loans and advances, deposits, total assets, non-performing loans and equity for 7 years were collected from the annual reports of sample DMBs. In the collection of banks in the survey, a non-probability approach was used in the context of a judgmental sampling method. The sample banks are First Bank of Nigeria Limited, Zenith Bank Plc, GT Bank Plc, United Bank for Africa Plc and Access Bank Plc. The following criteria were used in selecting the five banks: availability of consistent data set over the period, the bank's shares are listed and actively traded on the Nigeria Stock Exchange and over $60 \%$ banking sector assets are held by these banks (Financial Times London Publication July 2012). The study adopts the secondary sources of data collection. Data were obtained from the annual reports of the five DMBs for a period of seven years (2012 -2018). Data were extracted from risk management disclosure reports, financial statements, and notes to accounts in the annual reports. The variables are return on equity, non-performing loans, deposits and loans and advances. The time frame of seven years was used because of availability of consistent data.

\subsection{Model Specification}

The model specification is derived from the studies done by Kargi (2011), which attempted a study on credit risk and performance of Nigeria banks. This study improved on the model by adding the ratio of loans and advances to total deposits as independent variable and ratio of profit after tax to equity was used as dependent variable. ROE measures profitability from the shareholders point of view. It is on this basis that this model is adopted for this study.

$$
\mathrm{ROE}=\beta 0+\beta 1 \mathrm{NPL}+\beta 2 \mathrm{LADVS}+\beta 3 \mathrm{TDEPS}+\varepsilon
$$

The connection of X (NPLR, TDEPS, and LADVS) to Y is defined by the regression function (ROE). The constant term is $\beta 0$ and the feature coefficient is $\beta 1-\beta 3$, the value for the regression equation to estimate the variances independent of the independent variables is the value. This suggests that the indicator or independent variable adversely impacts the dependent variable if the $\beta 0$ coefficient is negative. The dependent variable would be decreased by the value of the coefficient by one unit increase in the independent variable. If the coefficient of 
$\beta 1-\beta 3$ is positive, the dependent expected that if independent variables equal zero, they will have (if $\beta 1, \beta 2, \beta 3$ $=0$ then $\beta 0=\mathrm{Y}$ ).

Definition and Measurement of Variables Standard

$\beta 0=$ Constant

$\beta 1-\beta 3=$ coefficient of the functions

$\varepsilon=$ error term

$\mathrm{ROE}=$ Return on equity as a measure of bank profitability.

NPL $=$ Non-Performing Loans as measure of credit risk

LADVS = Loans and Advances as a measure of credit risk

TDEPS $=$ Total deposits as a measure of liquidity risk

\subsection{Dependent variable}

The dependent variable in this study is bank profitability which is measured as return on equity. Return on equity and return on assets has been widely used by researchers as an indicator of profitability. The reason for using ROE is because information about ROE is available in the annual reports of the banks and equity is the core measure of bank financial strength from a regulator's point of view. Also, ROE is a proper indicator for measuring profitability from a shareholder's point of view.

\subsection{Independent Variables}

This study used three independent variables namely non-performing loans ratio, loans and advances to total assets ratio to represent credit risk variables. Loans and advances to deposit ratio represent liquidity risk. NPLR is thus calculated as

Non performing loan amount

Total loan amount

Loans to deposits ratio is a liquidity ratio and thus calculated as

Total loans and advances

Total deposits

Loans and advances ratio represent the ratio of total loans and advances to total assets. This isa risk asset quality ratio. It calculated as

$\underline{\text { Total loans and advances }}$

Total assets

Methods of Data Analysis

The inferential statistics used in this study were Pearson correlation and multiple regression analysis. Regression is used to assess the relative predictive capacity of the independent variables on the dependent variable. The EViews 8.0 econometric software is employed in the different analyses conducted.

\section{Results and Discussion}

The purpose of this study is to find out the impact of liquidity and credit risk on the profitability of selected DMBs in Nigeria. The dependent variable for this study is bank profitability in (ROE) while the independent variables are non-performing loans (NPL), loans and advances (LADVR) and total deposits (TDEPS).The study employed secondary data collected from the annual reports of five quoted banks in the Nigerian Stock Exchange for the periods 2012 to 2018 for the empirical analyses. To this end, the study used Pearson correlation and multiple least squares regression techniques for the empirical testing.

Data Presentation and analysis for the Dependent and Independent Variables

\subsection{Correlation Matrix}

Correlation measuresthe degree of linear relationship between the dependent variable and independent variables. The coefficient of the correlation results revealed that bank profitability in Nigeria has a weak positive correlation relationship with non-performing loans $(\mathrm{NPL}=0.32)$, loans and advances (LAVDS=0.29) and total 
deposits (DEPS=0.36). Non-performing loans (NPL) has a weak positive correlation relationship with bank profitability in Nigeria ( $\mathrm{ROE}=0.32$ ), loans and advances (LAVDS=0.24) and total deposits (DEPS=0.19). Loans and advances have a weak positive correlation with bank profitability in Nigeria (ROE $=0.36$ ), non-performing loans (NPL=0.19) and a high positive relationship with total deposits (DEPS=0.808). The variable, total deposits has a strong positive correlation with loans and advances (LAVDS=0.82) while a weak positive correlation relationship bank profitability in Nigeria $(\mathrm{ROE}=0.36)$ and non-performing loans (NPL=0.19). A better understanding at the significance of the effects of the correlation coefficient shows that between loans and advances and overall deposits there is a strong positive correlation link. The consequence of the correlation coefficients have showed that between the variables there is a poor positive correlation link. The matrix of correlation also showed that there were no two explanatory variables completely correlated. This suggests that the issue of multicollinearity in our model is missing. In the approximate model coefficients, and the bias of the standard coefficient errors, multicollinearity between explanatory variables can result in incorrect signs or implausible magnitudes. Therefore, the correlation result is presented.

Table 1. Pearson Correlation Matrix Result

\begin{tabular}{|l|l|l|l|l|}
\hline Variable & ROE & NPL & LADVS & TDEPS \\
\hline ROE & 1.00 & 0.32 & 0.29 & 0.36 \\
\hline NPL & 0.32 & 1.00 & 0.24 & 0.19 \\
\hline LAVDS & 0.29 & 0.24 & 1.00 & 0.82 \\
\hline DEPS & 0.36 & 0.19 & 0.82 & 1.00 \\
\hline
\end{tabular}

Source: Author's Computation

Data Presentation and Analysis for Hypothesized Relationships between Dependent and Independent Variables

\subsection{Regression Results}

The study employed white heteroskedasticity regression technique, Breusch-Pagan Godfrey heteroskedasticity diagnostic test and Ramsey Reset techniques to examine the impact of liquidity and credit risk on DMBs profitability in Nigeria. The regression results obtained using multiple least square is presented in table

Table 2. White Heteroskedasticity Regression Result

\begin{tabular}{|l|l|l|l|}
\hline Variable & Coefficient & T-test & P-value \\
\hline C & -0.03 & -0.30 & 0.7628 \\
\hline NPL & 5.54 & 1.30 & 0.2014 \\
\hline LAVDS & -0.08 & -0.41 & 0.6808 \\
\hline DEPS & 0.55 & 2.34 & 0.0253 \\
\hline
\end{tabular}

$\mathrm{R}_{2}=0.197818$

Adj. $R_{2}=0.120188$

Wald F-statistic $=3.110512$

Prob (F-stat. $)=0.040484$

Durbin Watson= 1.363243

From the regression result in table 2, the adjusted R-squared value of 0.120188 shows that $12 \%$ of the systematic variation in the bank profitability is jointly explained by non-performing loans, loans and advances and total deposits. The remaining $88 \%$ is due to exogenous factors which is represented in the model by the error term. The Wald F-statistics value of 3.110512 and its associated p-value of 0.040484 show that the model overall is statistically significant. This means that there exists a significant linear relationship between the dependent and independent variables in the model. Based on the results, non-performing loans (NPL) as a credit risk variable has a positive coefficient (5.54) and an insignificant (1.30) impact on bank profitability measured by return on equity (ROE). This indicates that the insignificant of non-performing loans was because the variable failed the individual test of significance even at 5\% level of significance. This in other words means that non-performing loans as credit risk of banks is not the main determinant ofDMBs profitability in Nigeria.Loans and advances (LAVDS) as a credit risk variable has a negative coefficient (-0.08) and an insignificant (-0.41) impact on bank profitability in Nigeria. The insignificant of loans and advances is because the variable failed the individual test of significance even at 5\% level of significance. This implies that loans and advances have a negative impact on the profitability of DMBs in Nigeria. In the case of total deposits, the variable has a positive coefficient $(0.55)$ and a significant (2.34) impact on bank profitability in Nigeria at 5\% level of significance. This means that increase in total deposits would significantly lead to increase in DMBs profitability in Nigeria. The significance 
of total deposits is because the variable passes the individual test of significance at $95 \%$ level of confidence. This, therefore, means that a total deposit measuring liquidity is the main determinant of bank profitability in Nigeria.

To test for the presence of heteroskedasticity in the regression result, a Breusch-Pagan Godfrey heteroskedasticity diagnostic test is conducted. The result shows that the high probability value of F-statistic (0.1157) or insignificant of the F-statistic reveals the absence of heteroskedasticity in the multiple least square regressions. In addition, to check for linear trend and misspecification of the model, a Ramsey RESET test is conducted. The result from the Ramsey RESET test reveals that the insignificance of Fitted 2 to Fitted ${ }^{\wedge} 5$ $(0.2749 .0 .2711,0.2656$ and 0.2514$)$ show that there is a linear trend in the model employed for the study. The Durbin-Watson value of 1.363243 reveals the absence of autocorrelation in the result. This in other words means that the result of this study is very sound for decision making by management and policy makers.

\subsection{Discussion}

From the empirical findings, it would be observed from the correlation coefficients result revealed that a weak positive correlation relationship exists between the variables. The correlation matrix also revealed that no two explanatory variables were perfectly correlated. This means that there is the absence of multicollinearity problem in our model. The regression results reveal that non-performing loan as a credit risk variable has a positive and an insignificant impact on bank profitability measured by return on equity (ROE) at even 5\% level of significance. This finding negates the findings of Felix and Chaudine (2008) and Harcourt (2017) that ratio of non-performing loans to total loans has a significant negative impact on bank profitability using return on equity(ROE). Loans and advances as a credit risk variable have a negative and insignificant impact on DMBs profitability in Nigeria.This finding negates Kargi (2011) that loans and advances inversely influenced bank profitability measured by return on equity and Harcourt (2017)who finds a positive insignificant relationship between ratio of total loans and advances to total assets and ROE. Liquidity risk has a positive and a significant impact on DMBs profitability in Nigeria. This result is consistentJavaid (2010) that total deposits inversely impactbank profitability.

\section{Conclusions}

Bank liquidity should be monitored and managed because it is the important determinant of DMBs profitability in Nigeria. The present paper examines the connection between liquidity, credit risk and DMBs profitability. The resultsuggests that liquidity is the main determinant of profitability of DMBs in Nigeria. If bank managers give less attention liquidity management, it would significantly lead to a decrease in profitability in Nigeria. Liquidity strengthens the ability of banks to meet their obligations. The implication for managers is the adoption of an efficient mechanism for monitoring,controlling and managing liquidityin DMBs. Indeed, DMBs should maintain optimal level of liquidity to reduce cash sterility in the assets of banks. Though credit risk is not the main determinant of DMBs profitability; effective strategies should be put in place to monitor, control, and manage credit risk (Greening and Bratanovic, 2003). It is recommended that DMBs should implement sound lending policy. The strategy should set out the methodology and goals of the bank's lending, with modalities for execution, supervision, evaluation and analysis. Since lending involves taking risks and evaluating the risks of interest rate defaults and movements, a written strategy will serve as a roadmap for management and lending institutions to guide them.

\subsection{Limitation of the Study}

The shortcomings of this analysis are established such that, within the context of the study, the results could be understood correctly. Areas like population, survey, methodology and data are the restrictions of the analysis. The sample of five DMBs somewhat limits the generalization of this study beyond this context.It implies that other DMBs were not included. Future research should add more dependent and independent variables to enhance our understanding of the subject. The longer period could be used in further research to ascertain if the result will be different from the current study. The choice of independent variables is the initiative of the researcher; therefore, the regression model might be subjective.

\section{References}

1. Agbada, A.O. And Osuji, C. C. (2013). The Efficacy of Liquidity Management and Banking Performance in Nigeria. International Review of Management and Business Research, (2) 1 
2. Al-Khouri, R. (2011).Assessing the Risk and Performance of the GCC Banking Sector,International Journal of Finance and Economics ISSN 1450-2887,Issue 65, 72-8.

3. Badawi, A. (2017). Effect of Credit Risk, Liquidity Risk, and Market Risk Banking to Profitability Bank (Study on Devised Banks in Indonesia Stock Exchange). European Journal of Business and Management 9(29), 1-8.

4. Bessis, J. (2010). Risk management in banking (3rd edition). New Jersey: Wiley

5. Boahene, S., Dasah, J., \& Agyei ,S. (2012). Credit risk and profitability of selected bank in GhanaResearch Journal of finance and accounting.

6. Bordeleau, E \& Graham, C. (2010). The Impact of Liquidity on Bank Profitability. Bank of Canada. Working Paper/Document No. 38.

7. Chen, K. and Pan, C. (2012).An Empirical Study of Credit Risk Efficiency of Banking Industry in Taiwan. Web Journal of Chinese Management Review,15(1),1-16.

8. Ejoh, N., Okpa, I \& Inyang, E. (2014). The Relationship and effect of Credit and Liquidity Risk on Bank Default Risk among Deposit Money Banks in Nigeria. Research Journal of Finance and Accounting, 5(16), 142-150

9. Epure, M. and Lafuente, I. (2012).Monitoring Bank Performance in the Presence of Risk,Barcelona GSE Working Paper Series No.61

10. Goddard, J., Molyneux, P. and Wilson, J. (2004). The Profitability of European Banks: a CrossSectional and Dynamic Panel Analysis. Manchester School 72 (3).

11. Greuning, H., \& Bratanovic, S. (2009). Analyzing banking risk. A framework for assessing corporate governance and risk management. 3rd Edition Washington, USA: World Bank.

12. Greuning, H., \& Bratanovic, S. (2003). Analyzing banking risk. A framework for assessing corporate governance and risk management: World Bank Publications.

13. Harcourt, E. E. (2017). Credit Risk Management and Performance of Deposit Money Banks in Nigeria. International Journal of Managerial Studies and Research (IJMSR), 5(8), 47-57.

14. Heibati F, Nourani S, and Dadkhah S. (2009). Evaluation of the Performance of Private banks of Iran in Comparison to the banks of Arabic countries, Persian Gulf area (domain). Economic Research Letter, 6:

15. Ibe, S. O.(2013). The Impact of Liquidity Management on the Profitability of Banks in Nigeria. Journal of Finance and Bank Management 1(1);

16. Imad, R. Kilani Z, Q., and Kaddumi T. (2011). Determinants of Bank Profitability: Evidence from Jordan. Int. J.Acad. Res. 3(4):.

17. Javaid,S.(2011).Determinants of bank profitability in Pakistan. internal factor analysis. Journal of Yasar University 23(6), 3794-3804.

18. Kargi, H. (2011).Credit risk and the performance of Nigeria banks. Ahmadu Bello University Zaria

19. Kolapo, T., Ayeni, R., \& Oke, O.(2012).Credit risk management and banks performance.Australian Journal of Business and Management Research.

20. Lartey, V. C., Antwi, S\&Boadi, E. K. (2013), "The Relationship Between Liquidity and Profitability of Listed Banks in Ghana. International Journal of Bisiness and Social Science, Vol. 4 No. 3: March 2013.

21. Maaka Z.A (2013). The relationship between liquidity risk and financial performance of commercial banks in Kenya. A research submitted to school of business, University of Nairobi

22. Matyszak, P.(2007).Ancient rome on five denarri a day (1st ed), NewYork, Thames \& Hundson

23. Muasya, B. (2009). The impact of non-performing loans on the performance of banking sector in Kenya, Unpublished MBA Project, University of Nairobi

24. Nwaze,C.(2006).Bank fraud exposed with cases and preventive measures ( $1^{\text {st }}$ ed), Lagos, control and survelliane associates ltd

25. Obiakor, R. T\& Okwu, A. T. (2011). Investigating Liquidity - Profitability Relationship in Business Organisation: A Study of Selected Quoted Companies in Nigeria. British Journal of Economics, Finance and Management Sciences, (1)2.

26. Owojori, A. A, Akintoye, I. R \& Adidu, F.A (2011). The challenge of risk management in Nigerian banks in the post consolidation era. Journal of Accounting and Taxation, 3 (2), 23-31.

27. Wild, J., Subramanyam, K., \& Halsey, R.(2007). Financial statement analysis ( ${ }^{\text {th }}$ ed.).NewYork, NY McGraw-Hill Irwin 